\title{
Penyelesaian Dugaan Kelalaian Medik Melalui Mediasi (Studi Pasal 29 Undang-Undang No. 36 Tahun 2009 Tentang Kesehatan)
}

\section{Didith Prahara}

Dosen Institut Agama Islam Negeri Ternate, Email: didit@iain-ternate.ac.id

\begin{abstract}
The regulation regarding mediation in the realm of criminal law (Penal Mediation) in Indonesia has not been fully implemented and is only a discourse and is a renewal of ideas for criminal law. In the process of medical negligence that occurs under the criminal law of Article 29 of Law No. 36/2009 actually has an important role if the medical dispute resolution agency in question already exists so that it can be resolved through that agency. However, if there is no medical dispute, which is directed at the realm of criminal law, it can be mediated on the condition that the criminal law violation is in the minor / minor category and law enforcement officials use their authority to exercise discretion. Thus, it is necessary to reform criminal law to resolve medical dispute problems, but if the Criminal Code does not have regulations governing legal settlement of medical disputes then alternatives must be made, namely the enactment of PERKAP, PERJA and PERMA.
\end{abstract}

Keywords: Medical Negligence; Mediation; Penal Mediation

\section{PENDAHULUAN}

Hubungan sosial yang dilakukan manusia dengan manusia dalam hal ini dokter dan pasien tidak lepas dari ikatan kerja sama dan permasalahan yang akan terjadi di dalamnya. Kondisi ini berlaku juga dalam dunia kesehatan khususnya tindakan pelayanan kesehatan (medik) yang diberikan dokter kepada pasien terikat dengan kontrak terapeutik. Begitu banyak dan rumitnya kasus kesehatan yang bermunculan pada akhir-akhir ini, menuntut solusi yang berkeadilan bagi dokter dan pasien sebagai pihak yang memiliki hubungan kontrak terapeutik. Tercatat, dalam beberapa tahun belakangan ini profesi dokter banyak menghadapi tuntutan hukum, setidaknya ada 405 laporan masalah medis dari berbagai daerah di Indonesia yang diterima oleh Lembaga Bantuan Hukum Kesehatan. ${ }^{1}$

Seiring perkembangan zaman dan pola pikir masyarakat, serta semakin berkembangnya kesadaran masyarakat akan perlindungan hukum, menjadikan hubungan dokter-pasien bukan saja sebagai hubungan keperdataan namun bahkan juga berkembang sehingga menyentuh pada persoalan pidana, terutama jika muncul kecurigaan dalam diri pasien bahwa ada tindakan malpraktek yang dilakukan dokter. Perlindungan dan penegakan hukum di Indonesia di bidang kesehatan terlihat jelas masih sangat kurang. Satu demi satu terdapat beberapa contoh kasus yang terjadi terhadap seorang pasien yang tidak

\footnotetext{
${ }^{1}$ Wasisto B, Suganda S. Perilaku profesional sebagai kontinum etis, disiplin dan hukum dalam mencegah masyarakat gemar menggugat (litigious society). Proceeding Pertemuan Nasional IV Jaringan Bioetika dan Humaniora Kesehatan Indonesia (JBHKI). Dikutip dalam Dedi Efendi, mediasi dalam sengketa medis, Majalah Kedokteran Indonesia, Volum: 59, Nomor: 5, Mei 2009.
} 
mendapatkan pelayanan semestinya, yang terburuk, dan kadang-kadang akan berakhir dengan kematian. Berlakunya Undang-undang No.36 Tahun 2009 tentang Kesehatan, memberi peluang bagi pengguna jasa atau pasien untuk mengajukan gugatan/tuntutan hukum terhadap pelaku usaha apabila terjadi konflik antara pelanggan dengan pelaku usaha yang dianggap telah melanggar hak-haknya, terlambat melakukan / tidak melakukan sesuatu yang menimbulkan kerugian bagi pengguna jasa/barang, baik kerugian harta benda atau cedera atau bisa juga kematian. Hal Ini memberikan arti bahwa pasien selaku konsumen jasa pelayanan kesehatan dapat menuntut/menggugat rumah sakit, dokter atau tenaga kesehatan lainnya jika terjadi konflik. ${ }^{2}$

Belakangan media massa mulai sering mengungkap ketidakpuasan pasien atau keluarga pasien terhadap pelayanan kesehatan yang mereka terima, baik dari dokter ataupun dari lembaga pelayanan kesehatan. Media elektronik maupun cetak yang mengangkat kasus dugaan malpraktek akibat kelalaian yang dikaitkan dengan kecacatan atau kematian seseorang setelah dilakukannya prosedur pengobatan. ${ }^{3}$ Tidak jarang masalah tersebut kemudian berlanjut hingga ke pengadilan. Kejadian ini menarik untuk dicermati mengingat sengketa medis seperti ini tidak terbayang akan terjadi dalam beberapa dekade lalu.

Jika dipelajari lebih dalam inti dari masalah yang dipaparkan diatas maka dapat dilihat bahwa selain kelalaian yang dibuat oleh tenaga kesehatan seperti dokter, terdapat juga masalah lain yaitu, semakin larutnya masalah yang terjadi tersebut. Dengan jalur litigasi yang ditempuh membuat segala permasalahan menjadi lebih kompleks dan lama dan pemberitaan yang gencar sehingga mengakibatkan Tenaga kesehatan atau rumah sakit yang lain yang tidak terlibat masalah ini mendapatkan stigma negatif dari masyarakat. Hal ini berdampak buruk pada pencitraan Rumah Sakit tersebut karena kehilangan kepercayaan sebagai sarana pelayanan kesehatan masyarakat. Di Indonesia sendiri, sengketa medis yang diselesaikan melalui jalur litigasi tidak banyak. Biasanya sengketa ini terhenti pada saat pembuktian, dimana pasien tidak dapat membuktikan kesalahan atau kelalaian dokter. Namun, untuk mencapai tahap pembuktian sendiri bukanlah sesuatu yang mudah. Padahal asas hukum yang berlaku dalam peradilan Indonesia seharusnya memenuhi asas sederhana, murah, dan cepat.

Dalam hal ini kasus sengketa medis sangat dimungkinkan untuk menyelesaikannya melalui mediasi. Hal ini tertuang dalam Perubahan Undang-Undang No. 23 Tahun 2002 tentang Kesehatan menjadi No. 36 Tahun 2009 tentang Kesehatan, memerintahkan wajib melakukan mediasi jika terjadi kesalahan atau kelalaian oleh tenaga kesehatan seperti pada pasal 29 sebelum di tempuh jalur hukum lainnya. ${ }^{4}$ Dibandingkan dengan metode alternatif penyelesaian sengketa lain yang sering dikerjakan oleh para pihak dan dokter, mediasi menawarkan penawaran yang integratif yang prosesnya tidak membutuhkan biaya yang besar serta waktu yang lama, dan tidak menekan pada siapa yang menang atau siapa yang kalah, siapa benar atau salah, tetapi dengan hasil penyelesaian menang menang (win win solution). Hal yang bagus lagi dalam mediasi

\footnotetext{
${ }^{2}$ Muhamad Amir Rahim, Dkk, kebijakan hukum pidana dalam penanganan tindak pidana malpraktik kedokteran, Sumatra selatan, data dari puskesmas sinjai, di ambil dalam Email:m.amirrahim@yahoo.com ${ }^{3} \mathrm{Op}$, cit., hal 9

${ }^{4}$ Pasal 29 Undang-Undang No. 36 Tahun 2009 tentang kesehatan "Dalam hal tenaga kesehatan diduga melakukan kelalaian dalam menjalankan profesinya, kelalaian tersebut harus diselesaikan terlebih dahulu melalui mediasi."
} 
sengketa medik biasanya focus kepada tujuan-tujuan dari pihak yang mengsengketakan (Pasien atau keluarganya) yang menjadi pokok pemufakatan. ${ }^{5}$

Dalam prektek mediasi penal muncul sebagai salah satu pemikiran alternatif dalam pemecahan masalah sistem peradilan pidana. Hal ini barawal dari wacana restorative justice yang berupaya untuk mengakomodir kepentingan korban dan pelaku tindak pidana, serta mencari solusi yang lebih baik untuk kedua belah pihak, dan mengatasi berbagai persoalan sistem peradilan pidana yang lain. Mediasi penal yang merupakan bagian dari konsep restorative justice menempatkan peradilan pada posisi mediator. Tapi dalam pelaksanaannya di Indonesia mediasi penal ini hanya berorientasi pada kasus pidana ringan seperti kekerasan dalam rumah tangga (KDRT) dan kejahatan anak, sedangkan dalam masalah sengketa medis jarang digunakan jika menyangkut tentang kelalaian yang mengakibatkan cacat atau hilangnya nyawa seseorang. Oleh karena itu penulis merasa perlu dikaji kembali tentang cara penyelesaian mediasi jika terjadi kelalaian pada profesi kedokteran dan berarah pada ranah pidana dikarenakan adanya multitafsir dari pasal 29 Undang-Undang No. 36 Tahun 2009. Penulis juga ingin menelaah kedudukan dari pasal 29 Undang-Undang No. 36 Tahun 2009 dalam sistem peradilan di Indonesia.

\section{METODE PENELITIAN}

Penelitian ini menggunakan tipe penelitian hukum dengan menggunakan pendekatan empiris dan pendekatan perundang-undangan. Data yang digunakan merupakan data sekunder meliputi bahan hukum primer berupa penelitian yang bertujuan untuk memperoleh pengetahuan tentang bagaimana hubungan hukum dengan masyarakat dengan faktor-faktor yang mempengaruhi pelaksanaan hukum dalam masyarakat. Jenis penelitian ini dilakukan dengan mengadakan penelitian langsung dilapangan dengan tujuan untuk mengumpulkan data yang objektif yang disebut dengan data primer. ${ }^{6}$. Bahan-bahan hukum tersebut kemudian dianalisis secara kualitatif dan disajikan secara deskriptif analitis sehingga dapat menjawab permasalahan dalam kajian penelitian ini.

\section{ANALISIS}

Pelakasanaan mediasi dalam sengketa medik belumlah menjadi suatu hal yang lazim di lakukan di Indonesia bahkan tentang sengketa medik pun para praktisi hukum dan praktisi kesehatan masih belum "se-iya se-kata" baik dalam definisi maupun dalam implementasi penegakkan hukum.

Sengketa Medik adalah sengketa yang terjadi antara pasien atau keluarga pasien dengan tenaga kesehatan atau antara pasien dengan rumah sakit/fasilitas kesehatan. Biasanya yang dipersengketakan adalah hasil atau hasil akhir pelayanan kesehatan dengan tidak memperhatikan atau mengabaikan prosesnya. Padahal dalam hukum kesehatan diakui bahwa tenaga kesehatan atau pelaksana pelayanan kesehatan saat memberikan pelayanan hanya bertanggung jawab atas proses atau upaya yang dilakukan (Inspanning Verbintennis) dan tidak menjamin/ menggaransi hasil akhir (Resultalte Verbintennis).

Seorang pasien yang datang pada dokter atau rumah sakit biasanya membawa masalah kesehatan yakni; berupa gangguan kesehatan yang menyebabkan menurunnya atau hilangnya fungsi sebuah organ serta bisa ke dokter karena sakit, perih, atau gangguan yang lain yang membuat pasien tidak lagi menjalankan kegiatannya sehari-hari.

\footnotetext{
${ }^{5}$ Eddi Junaidi, 2011, Mediasi dalam penyelesaian sengketa medik, Rajawali press, Jakarta, hal. 39

${ }^{6}$ Abdulkadir Muhammad, Hukum dan Penelitian Hukum, PT. Citra aditya Bakti, Bandung, 2004, hal.53
} 
Kunjungan ke dokter bermaksud agar masalah atau penderitaan pasien ini dapat dipindahkan atau dihilangkan dengan pengetahuan dan keterampilan yang dimiliki dokter, namun bila dokter tidak dapat memenuhi harapan itu maka dokter berpotensi mendapatkan hukuman dari pasien atau keluarga pasien yang bersangkutan.

Biasanya pengaduan dilakukan oleh pasien atau keluarga pasien ke instansi kepolisian dan juga ke media massa. Akibatnya sudah dapat diduga pers menghukum tenaga kesehatan mendahului pengadilan dan menjadikan tenaga kesehatan sebagai bulanbulanan, yang tidak jarang merusak reputasi nama dan juga karir tenaga kesehatan ini. Sementara itu pengaduan ke kepolisian baik di tingkat Polsek, Polres maupun Polda diterima dan diproses seperti layaknya sebuah perkara pidana. Menggeser kasus perdata ke ranah pidana, penggunaan pasal yang tidak konsisten, kesulitan dalam pembuktian fakta hukum serta keterbatasan pemahaman terhadap seluk beluk medis oleh para penegak hukum di hampir setiap tingkatan menjadikan sengketa medik terancam terjadinya disparitas pidana. ${ }^{7}$

Sebenarnya lembaga mediasi bukanlah merupakan bagian dari lembaga litigasi, dimana pada mulanya lembaga mediasi berada diluar pengadilan. namun sekarang ini lembaga mediasi sudah menyebrang memasuki wilayah pengadilan. negara-negara maju pada umumnya seperti yang sudah dikatakan diatas antara lain Amerika Serikat, Jepang, Australia, singapore mempunyai lembaga mediasi, baik yang berada diluar maupun didalam pengadilan, dengan berbagai istilah antara lain, Court Integreted Meditation, Court Annexed Meditation, Court Dispute Relosution, Court Connected ADR, Court Based ADR dan lain-lain.

Untuk menguraikan lebih jauh peran mediasi dalam sengketa medik maka sebaiknya dibahas terlebih dahulu mengenai kedudukan dan pengimplementasian instrumeninstrumen yang mengatur tentang mediasi baik itu dalam lingkup pengadilan maupun diluar pengadilan, dan sebagai pelengkap maka ada baiknya di bahas juga tentang penerapan mediasi penal dalam kelalaian medik yang ada di Indonesia, bagaimana justifikasi dan pengimpelemntasiannya.

\section{Kedudukan dan Penerapan Pasal 29 UU No. 36 Tahun 2009 dalam Penyelesaian Kelalaian Medik}

Mediasi sebagai salah satu mekanisme penyelesaian sengketa alternatif diluar pengadilan sudah lama dipakai dalam berbagai kasus-kasus bisnis, lingkungan hidup, perburuhan, pertanahan, perumahan, sengketa konsumen dan sebagainya yang merupakan perwujudan tuntutan masyarakat atas penyelesaian sengketa yang cepat, efektif dan efisien. ${ }^{8}$ Sedangkan mediasi dalam ranah hukum kesehatan barulah diterapkan dengan adanya Undang-Undang Kesehatan Nomor 36 Tahun 2009 pasal 29 yang mengakomodir kelalaian medik yang dilakukan oleh petugas pelayanan kesehatan haruslah dimediasi terlebih dahulu.

Ada pandangan teoritis yang dapat menjelaskan apa yang menjadi faktor yang mendorong para pihak yang bersengketa melakukan mediasi. Pandangan teoritis merujuk pada kebudayaan sebagai faktor dominan. Berdasarkan pandangan ini, cara-

\footnotetext{
${ }^{7}$ M. Nasser, Sengketa Medis dalam Pelayanan Kesehatan, Disampaikan pada Annual Scientific Meeting UGM-Yogyakarta , Lustrum FK UGM, 3 Maret 2011. Hal. 3

${ }^{8}$ Bambang Sutiyoso, 2006, Penyelesaian Sengketa Bisnis: Solusi dan Antisipasi bagi Peminat Bisnis dalam Menghadapi Sengeketa Kini dan Mendatang, Yogyakarta, Citra Media, Hal. 66
} 
cara penyelesaian konsensus seperti negosiasi dan mediasi dapat diterima dan digunakan oleh masyarakat karena pendekatan itu sesuai dengan cara pandang kehidupan masyarakat itu sendiri. Masyarakat yang mewarisi tradisi kebudayaan yang menekankan nilai penting keharmonisan dan kebersamaan dalam kehidupan akan lebih dapat menerima dan menggunakan cara-cara konsensus dalam penyelesaian sengketa. Kebudayaan dapat dibentuk atau dipengaruhi oleh sejumlah faktor, antara lain agama.

Selain karena adanya pandangan teoritis, alasan kekuatan dari mediasi merupakan salah satu faktor yang mendukung para pihak untuk melakukan mediasi. Kekuatan mediasi yang digemari oleh para pihak sengketa adalah biaya yang ringan dan waktu yang singkat. Dengan kata lain bahwa mediasi ini merupakan penyelesaian sengketa yang efektif, singkat dan terjangkau. Dan hal ini yang menjadi nilai lebih bagi mediasi.

Para pihak sengketa tidak mungkin ada yang mau untuk menyelesaikan sengketa dengan cara yang bertele-tele, yang membuang waktu para pihak saja. Karena masih banyaknya kegiatan yang dilakukan oleh para pihak bukan hanya untuk berperkara di pengadilan. Sama juga dengan halnya biaya, para pihak sengketa pasti tidak mau mengeluarkan biaya yang terlalu banyak untuk menyelesaikan sengketa. Untuk membuat segala persengketaan menjadi lebih mudah maka para pihak lebih memilih dan lebih tertarik untuk melakukan penyelesaian sengketa perdata melalui mediasi. Walaupun di dalam mediasi ini tidak ada yang menang atau kalah, tetapi para pihak sengketa tetap lebih memilih untuk melakukan mediasi.

Jika kita berbicara mengenai kedudukan dari pasal 29 Undang-Undang nomor 36 Tahun 2009 maka kedudukan dari pasal 29 Undang-Undang No. 36 Tahun 2009 seharusnya diluar pengadilan yang artinya dalam pelaksanaannya harus ada "Costumer Care" yang menangani kasus kelalaian medik tersebut, jadi jika muncul adanya dugaan kelalaian medik yang dilakukan oleh dokter maka Costumer Care tersebut harus di utamakan fungsinya, hal ini dikarenakan jika kasus kelalaian medik tersebut sudah masuk ke pengadilan maka hakim lebih condong untuk memakai Perma Nomor 1 Tahun 2008 daripada Pasal 29 Undang-Undang Nomor 36 Tahun 2009 dikarenakan pengaturan Perma lebih jelas pemaparannya daripada Pasal 29 Undang-Undang No. 36 Tahun 2009. ${ }^{9}$

Costume Care disini dapat diartikan sebagai sebuah wadah atau lembaga yang nantinya menjadi tempat untuk menyelesaikan sengketa medik yang terjadi antara tenaga kesehatan dan pasien, peran dari Costumer Care dikhususkan agar dapat menyaring kasus-kasus yang nantinya dapat meringankan neraca kasus dipengadilan, sehingga pengadilan bisa mengurangi tumpukan perkara yang menggantung. Akan tetapi Costumer Care hanya menangani kasus-kasus yang berkaitan dengan sengketa medik saja sehingga dalam penerapan tidak dicampur adukkan dengan sengketa-sengketa yang lain.

Seperti yang dijelaskan dalam penjelasan Undang-Undang No. 23 Tahun 2009 Pasal 29 yang menjelaskan bahwa mediasi dilakukan bila timbul sengketa antara tenaga kesehatan pemberi pelayanan kesehatan dengan pasien sebagai penerima pelayanan kesehatan. Mediasi dilakukan bertujuan untuk menyelesaikan sengketa diluar pengadilan oleh mediator yang disepakati oleh para pihak. Jadi walaupun dalam Asas hukum Undang-Undang Kesehatan lebih tinggi dari Perma Tentang Prosedur mediasi di

\footnotetext{
${ }^{9}$ Diah Sulastri Dewi, ibid.,
} 
Pengadilan lantas tak membuat pasal dari Undang-Undang Kesehatan yang dipakai dalam pengambilan putusan di pengadilan, dalam hal ini pasal 29 Undang-Undang No. 36 Tahun 2009 tidak bertentangan dengan Perma No. 1 Tahun 2008, akan tetapi Pasal 29 ini lebih diartikan pada pembuatan suatu lembaga diluar pengadilan untuk mengakomodir kelalaian medik yang terjadi sehingga bisa diselesaikan diluar pengadilan.

Tapi dalam penerapannya jika ada penyelesaian sengketa medik diluar pengadilan oleh mediasi yang telah disepakati oleh pihak yang berperkara dalam hal ini dokter dan pasien maka akta dari hasil mediasi tersebut bisa dibawa ke pengadilan dan dibuat putusan untuk mengukuhkan hasil dari mufakat tersebut, dalam istilah hukum putusan tersebut dikenal dengan istilah Akte van Dadding.

Di Indonesia belum dikenal yang namanya mediasi yang menghentikan penyidikan atau penuntutan diluar pengadilan, hal ini berbeda dengan mediasi yang ada di Jepang dimana ada jalur untuk melaksanakan mediasi hal tersebut dengan istilah chotei atau wakai.

Wakai adalah kesepakatan diantara para pihak yang bersengketa dalam perkara gugatan tertentu, yang berisi penyelesaian sengketa dimuka hakim yang menangani kasus lititgasi tersebut. Sementara chotei, adalah kesepakatan di anatara para pihak yang bersengketa dalam perkara chotei tertentu, yang berisi penyelesaian sengketa dimuka komisi chotei. Chotei dapat digolongkan ke dalam chotei perdata dan chotei urusan keluarga. Di Jepang, kini wakai maupun chotei sangat banyak di gunakan keduanya didasari mempunyai kesamaan dalam hal mencari penyelesaian sengketa yang layak melalui kesepakatan diantara para pihak, maka meskipun ada perbedaan subjek penyelenggara maupun tata caranya mereka berdua merupakan suatu yang sama pada dasarnya. ${ }^{10}$

Di Indonesia dalam penerapan system mediasi di luar pengadilan dapat mengambil contoh dari chotei Jepang. Dikarenakan Chotei di Jepang adalah proses mediasi di luar litigasi berakar dari masyarakat Jepang yang tidak menyukai karakteristik litigasi. Chotei tidaklah dibuat Undang-Undang yang bersifat terpadu melainkan hanyalah delegasi secara spesifik menurut bidang persengketaan. Chotei perdata di Jepang uang bertujuan untuk mengindarkan litigasi dan menyelesaian sengketa melalui pembicaraan pada prinsipnya ditangani oleh pengadilan sumir. Perkara yang dimasukkan sebagai gugatan dapat dilimpahkan ke Chotei oleh pengadilan yang menerima permohonan gugatan bersangkutan. Namun kasus serupa tergolong sedikit jumlahnya. Pengadilan negri yang mempunyai bagian khusus Chotei adalah PN Tokyo dan PN Osaka. Pelaksanaan Chotei oleh pengadilan tinggi adalah hal yang sah menurut hokum, akan tetapi sangat jarang dilakukan. ${ }^{11}$

Jika dibuat perbandingan, maka penerapan Chotei dalam istilah yang lain di Indonesia haruslah diterapkan mengingat bahwa dalam pembuatan Perma No. 1 Tahun 2008 atas kerja sama dan bantuan dari pihak Jepang sehingga para ahli yang bergelut di bidang mediasi bisa merumuskan instrument hokum yang nantinya mengatur tentang mediasi di luar pengadilan sama seperti Chotei di jepang.

\footnotetext{
${ }^{10}$ Yoshiro Kusano. 2013, Kebijakan dan Administrasi Peradilan yang Mendukung Chotei dan Wakai di Jepang; Workshop Internasional Perkembangan Mediasi di Indonesia, Jepang, dan Australia Masa Kini Menuju Masa Depan, Gakushuin University, Cibinong, hal. 3

${ }^{11}$ Ibid., hal. 5
} 
Penyelesaian sengketa melalui mediasi dapat dicapai atau dihasilkan jika semua pihak yang bersengketa dapat menerima penyelesaiannya itu. Namun, ada kalanya karena berbagai faktor para pihak tidak mampu mencapai penyelesaian, sehingga mediasi berakhir dengan jalan buntu (deadlock, stalemate). Situasi ini yang membedakan mediasi dari litigasi, litigasi pasti berakhir dengan sebuah penyelesaian hukum, berupa putusan hakim. Meskipun penyelesaian hukum belum tentu mengakhiri sebuah sengketa, karena ketegangan diantara para pihak masih berlangsung dan pihak yang kalah selalu tidak puas. ${ }^{12}$

Perma No. 1 Tahun 2008 dalam penerapan senyatanya memperkuat pasal 29 UndangUndang nomor 36 Tahun 2009 ini, dikarenakan menjadi batu loncatan dalam penerapan mediasi di pengadilan. Tapi sayangnya dalam realita, pelembagaan yang mengakomodir mediasi kelalaian medik diluar pengadilan belumlah efisien sehingga kebanyakan kasus kelalaian medik yang terjadi langsung menuju ke pengadilan perdata atau pidana. ${ }^{13}$

Hal tersebut lantas menjadi kelemahan dari pasal 29 Undang-Undang Nomor 36 Tahun 2009 dikarenakan dalam sistem hukum ada payung hukum yang mengatur tentang penyelesaian mediasi sengketa medik diluar pengadilan yang bertujuan untuk membantu para pihak yang bersengketa untuk menyelesaikan masalah sengketa medik yang mereka dapati. Disamping itu juga, dapat membantu kinerja dari peradilan karena mengurangi beberapa kasus yang nantinya menjadi waitting list di pengadilan. tetapi Lembaga yang dimaksud dalam pasal 29 Undang-Undang No. 36 Tahun 2009 senyatanya belum ada realisasinya sehingga dalam kasus kelalaian medik yang terjadi kebanyakan kasus yang bisa diselesaikan dialihkan ke pengadilan atau kepolisian untuk proses penyelesaian.

\section{Kedudukan dan Penerapan Mediasi Penal dalam Penyelesaian Kelalaian Medik}

Setelah di teliti dan dikaji maka dalam penerapannya mediasi penal dalam kelalaian medik belum ada atau belum terealisasikan, hal ini diutarakan juga oleh Dewi ${ }^{14}$ bahwa "dalam penerapannya mediasi penal ini belum terlaksana karena kebanyakan kasus mediasi pada sengketa medis yang masuk condong berarah pada putusan akhir di Pengadilan dan sebagiannya lebih pada ganti rugi secara perdata". Akan tetapi hal ini tidak menyurutkan keinginan untuk menyelesaikannya secara mediasi.

Di Indonesia walaupun belum ada lembaga yang menjalankan proses mediasi penal di pengadilan tapi jika sudah ada sebelumnya hasil pembicaraan musyawarah antara pelaku (dokter atau tenaga kesehatan) dengan korban maka pengadilan akan mempertimbangkannya karena dalam peradilan di jaman sekarang fokus penyelesaiannya lebih pada pemulihan korban, pasien, juga lingkungan atau dikenal dengan istilah restorative justice. ${ }^{15}$

Dalam penilaian hakim, mediasi penal yang terjadi pada kelalaian medik bisa di lakukan jika kasus pidana atau pelanggaran yang terjadi itu masuk dalam kategori pidana ringan dan berujung pada delik aduan bukan pada delik umum. Sehingga mediasi dapat di

\footnotetext{
12 Takdir Rahmadi, 2010, Mediasi; Penyelesaian Sengketa Melalui Pendekatan Mufakat, Jakarta, Raja Grafindo Persada. Hal. 17

${ }^{13}$ Muh Nasser, ibid.,

${ }^{14}$ Wakil Ketua sekaligus Hakim di Pengadilan Negeri Cibinong

${ }^{15}$ Hasil wawancara dengan Diah Sulastri Dewi, Hakim Pengadilan Cibinong tertanggal 07-05-2014
} 
lakukan dalam penyidikan maupun penuntutan hal ini akan terealisasikan jika hakim melihat korban telah menyadari apa yang telah ia perbuat juga merasa bersalah atas tindakannya dan korban pun memaafkannya maka mediasi bisa di laksanakan. ${ }^{16}$

Menurut Mudzakkir mengemukakan beberapa kategorisasi sebagai tolok ukur dan ruang lingkup terhadap perkara yang dapat diselesaikan di luar pengadilan melalui Mediasi Penal adalah sebagai berikut: ${ }^{17}$

1. Pelanggaran hukum pidana tersebut termasuk kategori delik aduan, baik aduan yang bersifat absolut maupun aduan yang bersifat relatif.

2. Pelanggaran hukum pidana tersebut memiliki pidana denda sebagai ancaman pidana dan pelanggar telah membayar denda tersebut (Pasal 80 KUHP).

3. Pelanggaran hukum pidana tersebut termasuk kategori "pelanggaran", bukan "kejahatan", yang hanya diancam dengan pidana denda.

4. Pelanggaran hukum pidana tersebut termasuk tindak pidana di bidang hukum administrasi yang menempatkan sanksi pidana sebagai ultimum remedium.

5. Pelanggaran hukum pidana tersebut termasuk kategori ringan/serba ringan dan aparat penegak hukum menggunakan wewenangnya untuk melakukan diskresi.

6. Pelanggaran hukum pidana biasa yang dihentikan atau tidak diproses ke pengadilan (Deponir) oleh Jaksa Agung sesuai dengan wewenang hukum yang dimilikinya.

7. Pelanggaran hukum pidana tersebut termasuk kategori pelanggaran hukum pidana adat yang diselesaikan melalui lembaga adat.

Salah satu upaya penerapan keadilan restoratif yang dapat dilakukan oleh kepolisian dalam memaksimalkan penyelesaian dengan menggunakan mekanisme mediasi Penal. Penyelesaian perkara-perkara ini dapat dilakukan oleh kepolisian selaku garda utama sistem peradilan pidana, dengan kewenangannya yaitu diskresinya dalam menyelesaikan suatu perkara pidana. Bahkan pelaksanaan nilai-nilai keadilan Restoratif oleh aparat kepolisian telah diberikan suatu dasar hukum berupa Surat telegram rahasia Kabareskrim Kepolisian Negara Republik Indonesia No : STR/583/VII/2012 Tanggal 88-2012 Tentang Contoh Penanganan Kasus yang berkaitan dengan Konsep Restorative Justice, yang intinya menyatakan bahwa Restorative Justice dapat dijalankan walaupun belum terdapat payung hukum yang jelas (sudah ada 1 Undang-Undang Sistem Peradilan Pidana anak yang mengadopsi nilai-nilai restorative justice melalui mekanisme diversi) ${ }^{18}$

Dalam sistem peradilan indonesia dewasa ini terjadi pergeseran pandangan keadilan dimana dulu lebih menonjol peradilan yang retributif justice ke restorative justice. Jadi dalam peradilan di Indonesia setiap kasus yang mucul di peradilan harus di mediasi terlebih dahulu, hal ini telah dimulai dengan adanya Diversi pada Undang-Undang Sistem Peradilan Anak dan mediasi pada kasus-kasus Kekerasan dalam Rumah Tangga.

Perubahan paradigma keadilan ini dikarenakan dalam pidana kurungan tidak lagi efektif dalam penerapannya, sehingga proses pemulihan korban, pasien dan lingkungan secara musyawarah menjadi alternatif utama dalam pelaksanaannya hal ini sejalan dengan

\footnotetext{
${ }^{16}$ Ibid.,

${ }^{17}$ Mudzakkir, Dalam I Made Agus Mahendra Iswara, "Mediasi Penal Penerapan Nilai-Nilai Restoratif Justice dalam Penyelesaian Tindak Pidana Adat Bali”, Tesis, Program Pascasarjana Fakultas Hukum Universitas Indonesia, Jakarta, 2013, h.55-56.

${ }^{18}$ Ibid., Hal 208
} 
Pancasila sila ke-empat. Yang melihat bahwa rakyat Indonesia dalam menangani masalah harus bermusyawarah. Dan juga tidak terlepas dengan munculnya ide-ide yang sudah diutarakan sebelumnya seperti ide-ide pembaharuan hukum pidana (penal reform), dan ada yang dikaitkan dengan masalah pragmatisme. Latar belakang ide-ide penal reform itu antara lain ide perlindungan korban, ide harmonisasi, ide restorative justice, ide mengatasi kekakuan/formalitas dalam sistem yang berlaku, ide menghindari efek negatif dari sistem peradilan pidana dan sistem pemidanaan yang ada saat ini, khususnya dalam mencari alternatif lain dari pidana penjara (alternative to imprisonment/alter-native to custody). Latar belakang pragmatisme antara lain untuk mengurangi stagnasi atau penumpukan perkara ("the problems of court case overload") ${ }^{19}$, dan untuk penyederhanaan proses peradilan.

Telah dikemukakan sebelumnya bahwa berdasarkan hukum positif di Indonesia, penyelesaian sengketa di luar pengadilan hanya dimungkinkan dalam perkara perdata (lihat Pasal 6 UU No. 30/1999 Tentang: Arbitrase dan Alternatif Penyelesaian Sengketa). Untuk perkara pidana pada prinsipnya tidak dapat diselesaikan di luar pengadilan, walaupun dalam hal-hal tertentu, dimungkinkan adanya penyelesaian kasus pidana di luar pengadilan, antara lain :

a. Dalam hal delik yang dilakukan berupa "pelanggaran yang hanya diancam dengan pidana denda". Menurut Pasal 82 KUHP, kewenangan/hak menuntut delik pelanggaran itu hapus, apabila terdakwa telah membayar denda maksimum untuk delik pelanggaran itu dan biaya-biaya yang telah dikeluarkan kalau penuntutan telah dilakukan. Ketentuan dalam Pasal 82 KUHP ini dikenal dengan istilah "afkoop" atau "pembayaran denda damai" yang merupakan salah satu alasan penghapus penuntutan.

a. Dalam hal tindak pidana dilakukan oleh anak di bawah usia 8 tahun. Menurut UU No. 3/1997 (Pengadilan Anak), batas usia anak nakal yang dapat diajukan ke pengadilan sekurang-kurangnya 8 tahun dan belum mencapai 18 tahun. Terhadap anak di bawah 8 tahun, penyidik dapat menyerahkan kembali anak tersebut kepada orang tua, wali, atau orang tua asuhnya apabila dipandang masih dapat dibina atau diserahkan kepada Departemen Sosial apabila dipandang tidak dapat lagi dibina oleh orang tua/ wali/orang tua asuh (Pasal 5 UU No. 3/ 1997).

Ketentuan di atas hanya memberi kemungkinan adanya penyelesaian perkara pidana di luar pengadilan, namun belum merupakan "mediasi penal" seperti yang diuraikan di atas. Penyelesaian di luar pengadilan berdasar Pasal 82 KUHP di atas belum menggambarkan secara tegas adanya kemungkinan penyelesaian damai atau mediasi antara pelaku dan korban (terutama dalam masalah pemberian ganti rugi atau kompensasi) yang merupakan "sarana pengalihan/ diversi" (means of diversion)" untuk dihentikannya penuntutan maupun penjatuhan pidana. Walaupun Pasal 82 KUHP merupakan alasan penghapus penuntutan, namun bukan karena telah adanya ganti rugi/ kompensasi terhadap korban, tetapi hanya karena telah membayar denda maksimum

\footnotetext{
${ }^{19}$ Upaya untuk mengurangi beban pengadilan (penumpukan perkara), di beberapa negara lain juga ditempuh dengan dibuatnya ketentuan mengenai "penundaan penuntutan" ("suspension of prosecution") atau "penghentian/penundaan bersyarat" ("conditional dismissal/discontinu-ance of the proceedings") walaupun bukti-bukti sudah cukup, seperti diatur dalam Pasal 248 KUHAP (Hukum Acara Pidana) Jepang *) dan Pasal 27-29 KUHP (Hukum Pidana Materiel) Polandia. Barda Nawawi Arief, Kebijakan Legislatif dalam Penanggulangan Kejahatan dengan Pidana Penjara, BP UNDIP. Semarang, cetakan ke-3, 2000, hal. 169-171.
} 
yang diancamkan. Penyelesaian kasus pidana dengan memberi ganti rugi kepada korban, dimungkinkan dalam hal hakim akan menjatuhkan pidana bersyarat (Pasal 14c KUHP). Patut dicatat, ketentuan pidana bersyarat dalam KUHP inipun masih tetap berorientasi pada kepentingan pelaku (offender oriented), tidak "victim oriented".

Kemungkinan lain terlihat dalam UU No. 39/1999 tentang Pengadilan HAM yang memberi kewenangan kepada Komnas HAM (yang dibentuk berdasar Kepres No. 50/ 1993) untuk melakukan mediasi dalam kasus pelanggaran HAM (lihat Psl. 1 ke-7; Psl. 76:1; Psl. 89:4; Psl. 96). Namun tidak ada ketentuan yang secara tegas menyatakan, bahwa semua kasus pelanggaran HAM dapat dilakukan mediasi oleh Komnas HAM, karena menurut Pasal 89 (4) Komnas HAM dapat juga hanya memberi saran kepada para pihak untuk menyelesaikan sengketa melalui pengadilan (sub-c), atau hanya memberi rekomendasi kepada Pemerintah atau DPR untuk ditindaklanjuti penyelesaiannya (sub-d dan sub-e). Demikian pula tidak ada ketentuan yang secara tegas menyatakan, bahwa akibat adanya mediasi oleh Komnas HAM itu dapat menghapuskan penuntutan atau pemidanaan. Di dalam Pasal 96 (3) hanya ditentukan, bahwa "keputusan mediasi mengikat secara hukum dan berlaku sebagai alat bukti yang sah".

Telah dikemukakan di atas, bahwa di beberapa negara lain, mediasi penal dimungkinkan untuk tindak pidana yang dilakukan oleh anak dan untuk kasus KDRT (kekerasan dalam rumah tangga - domestic violence). Namun di Indonesia, ketentuan mediasi penal itu tidak terdapat dalam UU No. 3/1997 tentang Pengadilan Anak maupun dalam UU No. 23/2004 tentang KDRT.

Akhirnya patut dicatat, bahwa gugurnya kewenangan penuntutan seperti yang ada dalam KUHP (yang tersebar dalam beberapa pasal, antara lain Psl. 82 di atas), di dalam Konsep RKUHP digabung dalam satu pasal dan diperluas dengan ketentuan sbb. :

Pasal 145 (RKUHP 1-8-2006) (Psl. 142 RKUHP 2004) Kewenangan penuntutan gugur, jika:

a. telah ada putusan yang memperoleh kekuatan hukum tetap;

b. terdakwa meninggal dunia;

c. daluwarsa;

d. penyelesaian di luar proses;

e. maksimum pidana denda dibayar dengan suka-rela bagi tindak pidana yang dilakukan hanya diancam dengan pidana denda paling banyak kategori II;

f. maksimum pidana denda dibayar dengan suka-rela bagi tindak pidana yang diancam dengan pidana penjara paling lama 1 (satu) tahun atau pidana denda paling banyak kategori III;

g. Presiden memberi amnesti atau abolisi;

h. penuntutan dihentikan karena penuntutan diserahkan kepada negara lain berdasarkan perjanjian;

i. tindak pidana aduan yang tidak ada pengaduan atau pengaduannya ditarik kembali; atau

j. pengenaan asas oportunitas oleh Jaksa Agung.

Dari ketentuan RKUHP di atas terlihat, dimungkinkannya penyelesaian perkara pidana di luar pengadilan. Pengaturan rincinya belum ada, namun tentunya akan diatur lebih lanjut di dalam Rancangan KUHAP. 
Akan tetapi terkadang Mediasi penal sering dinyatakan merupakan "the third way" atau "the third path" dalam upaya "crime control and the criminal justice system" "20, dan telah digunakan di beberapa negara. Namun yang jelas, penyelesaian damai dan mediasi di bidang hukum pidana ini pun sebenarnya sudah dikenal dalam hukum adat dan dalam kenyataan sehari-hari.

Mediasi penal dalam perkara kelalaian medik juga bisa menjadi nonsense atau tidak berarti jika pada kasus yang terjadi dokter melakukan kelalaian yang mengakibatkan mati atau cacatnya seseorang, karena dalam sistem peradilan di Indonesia belum mengatur sampai sejauh itu, ada batasan-batasan yang mengatur tentang pidana ringan yang nantinya bisa di mediasi. Mahkamah Agung telah mengkategorikannya pada Perma Nomor 2 Tahun 2012, dimana dalam ganti rugi jika nominalnnya di bawah Rp 2.500.000 maka diwajibkan untuk memediasi terlebih dahulu.

Sedangkan mediasi dalam kelalaian medis senyatanya barulah pada tahap pengusulan draft oleh MHKI ke DPR RI jika ada perubahan RUU KUHP. MHKI mengusulkan sebelum KUHP berubah maka penjelasan mengenai sengketa medis melalui mediasi sebaiknya dapat dilakukan dengan menggunakan instrument-instrument sebagai berikut: ${ }^{21}$

a. PERKAP (Peraturan Kapolri)

Dimana dalam melakukan penyelidikan terlebih dahulu dilakukan mediasi oleh polisi pada kedua belah pihak yang bersengketa.

b. PERJA (Peraturan Jaksa Agung)

Yaitu pada tahap penyidikan Jaksa Agung atas kekuasaannya dapat memediasi kedua belah pihak yang bersengketa.

c. PERMA (Peraturan Mahkamah Agung)

Sama seperti Perma No.1 Tahun 2008 maka Mahkamah Agung dapat mengeluarkan Surat Edaran atau Peraturan agar dalam kasus kelalaian medik di wajibkan untuk memediasi terlebih dahulu.

Konsep mediasi penal sebagai salah satu bentuk ADR dapat dimungkinkan sebagai kebijakan ius constituendum dalam upaya memberikan perlindungan baik terhadap pasien maupun tenaga kesehatan yang bersengketa, karena konsep kelalaian medik berkaitan erat dengan konsep tentang kerugian dan kematian (penghilangan nyawa seseorang, akibat kecorobohan praktek kedokteran dan pengobatan), tentunya mediasi penal sebagai salah satu alternatif penyelesaian masalah di bidang hukum pidana secara teoritis lebih efisien, baik dari segi biaya, tenaga dan waktu, serta memiliki potensi untuk bisa melahirkan kesepakatan yang win-win solution.

Kesepakatan win-win solution ini menjamin keberlanjutan hubungan baik di antara para pihak yang bersengketa. Keberlanjutan ini sangat penting, karena terjadinya resistensi

\footnotetext{
${ }^{20}$ Deborah Macfarlane, Victim-Offender Mediation in France, http://www. Mediationconference.com.au/2006_Papers/Deborah\%20Macfarlane\%20\%20VICTIM\%20OFFENDER \%20MEDIATION\%20 IN\%20 FRANCE1.doc ; Christa Pelikan. On Restorative Justice, www. restorativejustice.org/resources/docs/pelikan; Dieter Rössner, Mediation as a Basic Element of Crime Control: Theoretical and Empirical Comments, wings.buffalo.edu/ law/bclc/bclrarticles/3(1)/roessner.pdf ; Tony Peters, in colla-boration with Ivo Aertsen, Katrien Lauwaert and Luc Robert : From Community Sanctions To Restorative Justice, The Belgian Example, www.unafei.or.jp/english/pdf/PDF_rms/ no61/ ch12. pdf

${ }^{21}$ Hasil wawancara dengan Muh Nasser, Komite Polisi Nasional tertanggal 27-04-2014
} 
masyarakat terhadap kehadiran usaha/kegiatan praktek kedokteran sangat diperlukan dalam kehidupan sehari-hari. Hal inilah pada kenyataannya seringkali dialami oleh dokter, perawat, apoteker juga bidan dalam menjalankan profesi usaha atau kegiatannya. Menyangkut kebijakan mediasi penal ini tentunya perlu diadakan payung/kerangka hukum (mediation within.the framework of criminal law) sebagai perwujudan asas kepastian hukum yakni bisa diintegrasikan dalam hukum pidana materiel atau hukum pidana formal (dalam peraturan perundang-undangan pidana yang berkaitan dengan masalah malpraktek di bidang medis).

M. Nasser ${ }^{22}$ dalam Hukum Online menegaskan aturan yang menyatakan kelalaian tenaga kesehatan tak bisa dipidana, tak melanggar asas hukum. Sebab, sesuai asas hukum lex specialis derogat lex generalis, aturan khusus dalam tiga paket undangundang bidang kesehatan dapat mengenyampingkan aturan umum sebagaimana tertuang dalam KUHP. "Kalau ada undang-undang yang specialis, undang-undang yang generalis terabaikan,"

Sebenarnya ia mengaku tidak sepakat jika kelalaian tak bisa dipidana sama sekali. Sebab, sesuai UU Praktik Kedokteran, masyarakat yang merasa dirugikan atas tindakan dokter/dokter gigi dapat melaporkan kepada MKDKI. Jika terbukti melanggar kode etik, hasilnya diteruskan kepada organisasi profesi untuk dijatuhi sanksi berupa teguran tertulis, pencabutan izin praktik, atau diwajibkan mengikuti diklat. Laporannya itu tak menghilangkan hak masyarakat untuk melapor secara pidana atau menggugat perdata di pengadilan. "Jadi kelalaian yang dilakukan tenaga kesehatan bisa saja dipidana jika kelalaian yang dilakukan sangat fatal atau berulang-ulang yang tidak semestinya dilakukan seorang dokter terdidik," Karena itu, penegakan hukum dalam soal ini dapat diterapkan secara adil tanpa pandang bulu. Dampaknya, kualitas pelayanan kesehatan kepada masyarakat akan meningkat karena tenaga kesehatan atau dokter akan bersikap hati-hati. $^{23}$

Muhammad Arif Setiawan ${ }^{24}$ berpendapat kesulitan utama penegakan hukum kesehatan soal pembuktian ketika adanya dugaan malpraktek yang dilakukan dokter. Belum lagi, informasi medis tak diketahui banyak oleh pasien. "Dari sisi pasien membuktikan malpraktik itu kesulitan yang luar biasa karena sumber dana dan ahli tak dimiliki pasien, mendatangkan tenaga ahli tidak murah. Karena itu, mekanisme mediasi harus dikembangkan untuk menciptakan win win solution. Sebab, faktanya kondisi/posisi pasien sangat lemah. "Kondisi yang rusak itu perlu di-restorative justice untuk memperbaiki kesalahan. Dokter senang, pasien juga senang. Jika mekanisme mediasi tak bisa menyelesaikan, baru sanksi pidana yang menyelesaikan masalah ini sebagai ultimum remedium (upaya terakhir), ${ }^{25}$

Berdasarkan uraian tersebut diatas penyelesaian perkara tindak pidana yang dilakukan oleh aparat penegak hukumdapat diketahui penyelesian perkara pidana pada tingkata penyidikan dapat dilakukan penyelesaian secara damai diluar pengadilan.

Berdasarkan pandangan pihak kepolisian, jaksa penuntut umum, advocat, dan hakim penyelesaian perkara diluar pengadilan diakui terjadi dalam penyelesaian perkara

\footnotetext{
${ }^{22}$ M. Nasser. Vice President of word medical law.

23 http://www.hukumonline.com/berita/baca/lt4ce944de4b8d6/kelalaian-tenaga-kesehatan-tak-bisadipidana- Dipublikasikan : Minggu, 21 November 2010

${ }^{24}$ Dosen Fakultas Hukum di Universitas Islam Indonesia

25 Ibid.,
} 
pidana.pihak kepolisian yang paling banyak menyelesaikan tindak pidana diluar pengadilan dengan melakukan pendekatan diskresi. Penyelesaian oleh pihak kepolisian dilakukan umumnya pada perkara-perkara yang belum dibuatkan surat perintah dimulainya penyidikan (SPDP) kepda pihak pihak jaksa penuntut umum. Pihak kepolisisan umumnya memfasilitasi penyelesaian diluar pengadilan karena adanya permintaan yang umumnya dilakukan oleh para pelaku tindak pidana, bentuk fasilitasi yang diberikan adalah memberikan agar para pihak pelaku dan juga korban bernegosiasi, negosiasi dapat dilakukan dikantor kepolisian atau ditempat lain, hasil kesepakatan yang dilakukan oleh pelaku dan korban tindak pidan harus dituangkan dalam perjanjian tertulis dan telah diselesaikan dengan baik sehingga tidak lagi akan ada tuntutan pemenuhan isi perjanjian. Hasil kesepakatan yangdituangkan dalam perjanjian akan menjadi pijakan bagi pihak kepolisian mengambil diskresi. ${ }^{26}$

Jaksa penuntut umum jarang melakukan diskresi, atas dasar adanya peneyelesaian diluar pengadilan terkait adanya kesepakatan antara pelaku dan korban tindak pidana, kalaupun ada upaya penyelesaian perkara pidana dapat dituangkan dalam surat perjanjian perdamaian maka hal tersbut akan dilampirkan dalam berkas perkara dan menjadi dasar pertimbangan penuntutan untuk hal-hak yang meringankan.

Hakim pada pengadilan sebagaimana Jaksa Penutut Umum hanya akan memperrtimbangkan penyelesaian perkara pidana antara pelaku dan korban tindak pidana sebagai alasan meringankan dalam penjatuhan pidana apabila pelaku terbukti bersalah danmampu bertanggung jawab atas perbuatan pidana yang dilakukannya. Secara umum perkara-perkara yang diselesaikan secara damai, para korbanmenerima ganti kerugian. Namun para pelaku tindak pidana meskipun bersedia memberikan umumnya belum bersedia mengakui perbuatannya dan menyampaikan permohonan maaf secara terbuka kepada korban tindak pidana.

Berdasarkan uraian sebelumnya dapat diambil kesimpulan bahwa, mediasi pidana sebagai suatu konsep penyelesian perkara pidana dapat diterapkan dalam sistem peradilan di Indonesia, untuk itu diperlukan pengaturan dalam perundang-undangan sebagai dasar penerapannya.

\section{SIMPULAN}

Instrumen hukum yang mengatur tentang mediasi dalam sengketa medik seperti dalam pasal 29 Undang-Undang No. 36 Tahun 2009 haruslah mempunyai suatu lembaga yang nantinya menjadi tempat untuk menerapkan mediasi diluar pengadilan, belum adanya lembaga yang mengakomodir mediasi dalam sengekat medik mengakibatkan banyaknya kasus sengketa medik dibawa ke pengadilan perdata dan juga ditangani secara pidana oleh kepolisian. Dikarenakan dalam penyelesaian sengketa secara formal melalui peradilan sangat kaku dan mempunyai banyak kekurangan maka muncul instrument hukum yang mengatur mekanisme penyelesaian sengketa medik diluar pengadilan sehingga jika adanya dugaan kelalaian medik yang dilakukan oleh pelayanan kesehatan seperti pada bunyi Pasal 29 Undang-Undang No. 36 Tahun 20009 "Dalam hal tenaga kesehatan diduga melakukan kelalaian dalam menjalankan profesinya, kelalaian tersebut harus diselesaikan terlebih dahulu melalui mediasi" maka setiap perkara sengketa medik baik yang berarah pada ranah hukum perdata yang ada dapat

\footnotetext{
${ }^{26}$ Trisno Raharjo, 2011, Mediasi Pidana Dalam Sistem Peradilan Pidana; Suatu Kajian Perbandingan dan Penerapannya di Indonesia, Buku Litera, Yogyakarta, Hal. 111
} 
diselesaikan melalui mediasi diluar pengadilan. sedangkan Dalam ranah hukum pidana, mediasi yang dilakukan harus memenuhi beberapa syarat seperti pelanggaran hukum pidana tersebut termasuk kategori ringan/serba ringan dan aparat penegak hukum menggunakan wewenangnya untuk melakukan upaya diskresi.

\section{DAFTAR PUSTAKA}

Abbas, Syahrizal Mediasi : dalam hukum syariah, hukum adat, dan hukum nasional, Cetakan kedua, Jakarta, Kencana, 2011

Guwardi, J. Pengantar Ilmu hukum dan Bio-etika, Jakarta Fakultas Kedokteran UI: 2009

Hukum Medik (Medical Law), Jakarta, Fakultas Hukum Universitas Indonesia, 2004.

Tindakan Medik dan Tanggung Jawab Produk Medik, Jakarta. Fakultas Kedokteran Universitas Indonesia. 1993

Hendrik, Etika dan Hukum Kesehatan, Jakarta, buku kedokteran: 2011

Ide, Alexandra. Etika dan Hukum dalam Pelayanan Kesehatan; Cetakan ke-I, Grasia, Yogyakarta, 2012.

Junaidi, Eddi. Mediasi dalam Penyelesaian Sengketa Medik; Cetakan ke-I, Rajawali Press, Jakarta, 2011

Nasser, Muh. Medical Dispute In Indonesia Health, London, Springer Reference, 2012

Rahmadi, Takdir. Mediasi; penyelesaian Sengketa Melalui Pendekatan Mufakat. Jakarta, Raja Grafindo Persada. 2010.

Supriadi, Wila Chandrawila. Hukum Kedokteran, Bandung, Mandar Maju: 2001

\section{Peraturan PeruUndang-Undangan}

KUHP (Kitab Undang-Undang Hukum Pidana)

KUHPer (Kitab Undang-Undang Hukum Perdata)

Undang-Undang Republik Indonesia Nomor 32 Tahun 2009 Tentang Kesehatan

Undang-Undang Republik Indonesia Nomor 29 Tahun 2004 Tentang Praktek Kedokteran

Undang-Undang Republik Indonesia Nomor 30 Tahun 1999 Tentang Arbitrase dan Alternatif Penyelesaian Sengketa

\section{Jurnal}

Freckelton, Ian dan Petersen Kerry. Disputes and Dilemmas In Health Law, London. U.K, The Federation Press. 2006

Beran, Roy G. Legal and Forensic Medicine, Volume 3, London, U.K, Springer Reference, 2012

Kerridge, Ian and friends. Ethics and Law For The Health Professions, Second edition, London, U.K, The Federation Press. 2005

American College of Legal Medicine. The Medical Malpractice Survival Book, U.S.A, Mosbry Elsevier. 